\title{
PENERAPAN METODE ANALYTICAL HIERARCHY PROCESS (AHP) DAN SIMPLE ADDITIVE WEIGHTING (SAW) DALAM PEMILIHAN TEMBAKAU TERBAIK
}

\author{
Novica Irawati ${ }^{1}$, Muhammad Yasin Simargolang ${ }^{2}$, Yustria Handika Siregar ${ }^{3}$, Evi Kurnia Wati ${ }^{4}$ \\ ${ }^{\text {IS }}$ ekolah Tinggi Manajemen Informatika dan Komputer STMIK Royal \\ ${ }^{2,3}$ Teknik Informatika, Universitas Asahan, Jalan Ahmad Yani Kisaran, Indonesia \\ ${ }^{4}$ Sistem Informasi, Universitas Islam Negeri Sumatera Utara, Jalan Williem Iskandar Medan, Indonesia \\ novicairawatillegmail.com, muhammadyasinsegmail.com, yustria.siregar@gmail.com, \\ evikurniawatiegmail.com
}

\begin{abstract}
Indonesia is one of the good tobacco producing countries. Tobacco is a plant that is grown by farmers and is a seasonal agricultural product that functions as a material to fill one's spare time or commonly referred to as raw material for cigarettes and cigars. In addition, the function of tobacco is also as a medical raw material (drugs, and tobacco can also be chewed. From the known function of tobacco leaves. Therefore, there is a need for requirements in selecting the best termbakau leaves based on the criteria determined by the tobacco production company, namely elasticity. , light color, aroma, sorting, price. Therefore, the researcher built a decision support system for selecting the best tobacco leaf which later aims to make it easier for farmers to choose which leaves are suitable or not for production. This research uses two methods, namely the method Analytica Hierarchyl Process (AHP) to determine eigenvalues as well as consistency and Simple Additive Weighting (SAW) to determine the suitability rating and also the ranking results.
\end{abstract}

Keywords - Tobacco Leaves; AHP; SAW

\begin{abstract}
Abstrak - Negara Indonesia adalah salah satu negara penghasil tembakau yang baik. Tembakau adalah sebuah tanaman yang di ditanam oleh petani dan sifatnya produk pertanian musiman yang berfungsi sebagai bahan mengisi waktu luang seseorang atau biasa disebut dengan bahan baku rokok dan juga cerutu. Selain itu fungsi tembakau juga sebagai bahan baku medis (obat-obatan, dan juga tembakau dapat di kunyah. Dari fungsi daun tembakau yang telah diketahui. Maka diperlukan nya persyaratan dalam pemilihan daun termbakau yang baik berdasarkan kriteria yang sudah ditentukan oleh perusahaan produksi tembakau yaitu elastisitas, warna terang, aroma, sortasi, daya bakar (tahan lama). Oleh karena itu, peneliti membangun suatu sistem pendukung keputusan pemilihan daun tembakau terbaik yang nantinya bertujuan untuk memudahkan para petani memilih manakah daun yang layak atau tidak nya untuk di produksi. Penelitian ini menggunakan dua metode yaitu metode Analytica Hierarchyl Process (AHP) untuk menentukan nilai eigen dan juga konsisten dan Simple Additive Weighting (SAW) menentukan rating kecocokan dan juga hasil perangkingan.
\end{abstract}

Kata Kunci - Daun Tembakau; AHP; SAW

\section{PENDAHULUAN}

Daun Tembakau atau tabaco merupakan salah satu negara penghasil tembakau yang baik. Tembakau adalah sebuah tanaman yang di ditanam oleh petani dan sifatnya produk pertanian musiman yang berfungsi sebagai bahan mengisi waktu luang seseorang atau biasa disebut dengan bahan baku rokok dan juga cerutu[1].

Daun tembakau yang dipanen adalah daun tembakau yang memenuhi syarat kriteria yang telah ditentukan yaitu elastisitas, warna terang, aroma, sortasi, daya bakar (tahan lama). Dari kriteria tersebut nantinya dapat menghasilkan tembakau yang berkualitas baik[1].
Seperti yang telah kita ketahui bahwa tidak hanya di negara indonesia tetapi di negara-negara lain juga tembakau sangat banyak dibutuhkan sebagai bahan medis, dan juga bakan baku rokok.

Dengan pernyataan diatas dapat diidentifikasi masalah yang terjadi yaitu perusahaan yang masih kesulitan dalam memilih tembakau yang baik sesuai dengan persyaratan kriteria yang telah ditentukan yaitu elastisitas, warna terang, aroma, sortasi, daya bakar (tahan lama) dikarenakan sistem yang belum canggih. Masih menggunakan alat manual[2]. Oleh karena itu peneliti membuat sebuah sistem penerapan metode Analytical Hierarchy Process (AHP) dan Simple Additive Pocess (SAW) dalam pemilihan tembakau terbaik. 
Tujuan dari pembuatan sistem tersebut adalah untuk memudahkan para petani memilih manakah daun yang layak atau tidak nya untuk di produksi. Agar menciptakan produk tembakau yang baik bagi kuntungan daripada perusahaan tersebut[3].

\section{TINJAUAN LITERATUR}

Dalam suatu penelitian tentunya harus ada penjelasan yang detail mengenai sebuah penelitian yang sebelumnya yang berkaitan dengan topik yang akan dibuat.

Tembakau deli adalah tembakau yang terkenal di seluruh dunia dan mendapat gelar sebagai "Dollar Land". Tembakau deli juga di nobatkan sebagai tembakau yang memiliki daun pembukus cerutu terbaik didunia mengalahkan tembakau Brazil dan Kuba. Penelitin ini bertujuan unutuk menciptakan sebuah sistem aplikasi pemilihan tembakau deli yang terbaik dengan menggunakan metode promethee guna memberikan hasil keputusan yang baik [4].

Lain hal nya dengan penelitian yang sebelumnya. Penelitian ini membahas tentang Pemilihan Supplier Tembakau Sebagai Bahan Baku Rokok Menggunakan Metode Analytical Network Process (ANP) Di Pabrik Rokok Alaina [5]. Pada penelitian ini memiliki tujuan untuk mengetahui memilih dan menyeleksi mana saja kriteria yang kira-kira masuk kedalam pemilihan supplier tembakau sebagai bahan baku rokok.

\section{METODE PENELITIAN}

Pada penelitian ini dapat dijelaskan melalui gambar metode dibawah ini :

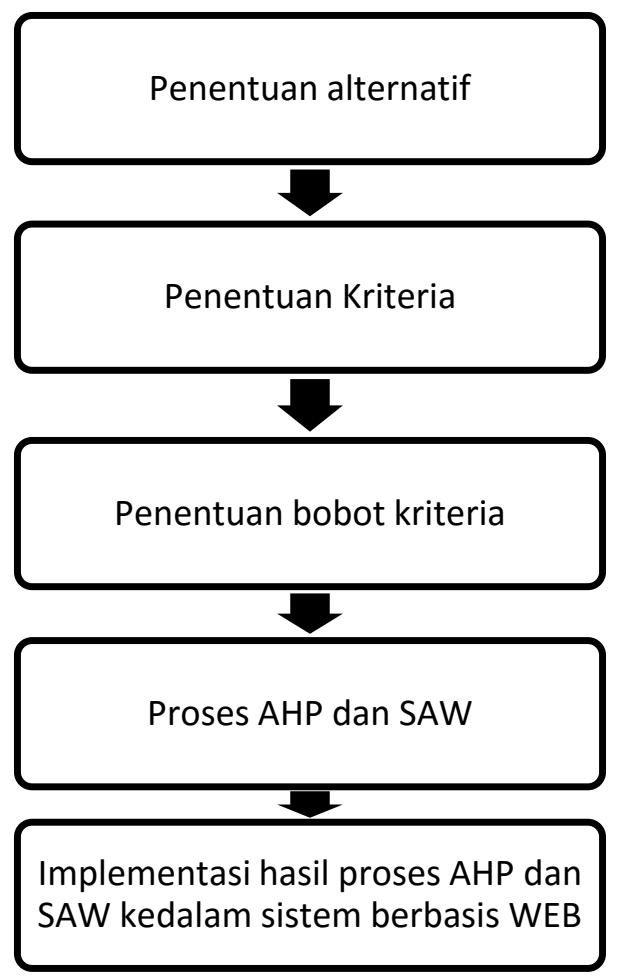

Gambar 1. Struktur Metode Penelitian.
Dari hasil gambar struktur penelitian diatas, dapat dijelaskan sebagai berikut :

1) Sebelum melakukan sebuah penelitian, peneliti harus menentukan alternatifnya terlebih dahulu sesuai dengan topik yang akan di bahas.

2) Setelah menentukan alternatif, selanjtnya adalah menentukan kriteria yang cocok terkait alternatif dan topik. Kriteria pada penelitian kali ini ditentukan dari persyaratan perusahaan tembakau nya sendiri sebagai pemilihan tembakau terbaik.

3) Kemudian, menentukan bobot kriteria yang masing masing bobot setiap kriteria pada penelitian kali ini semuanya sama (C1 20\%, C2 20\%, C3 20\%, C4 $20 \%$, C5 20\%).

4) Setelah selesai menentukan bobot, selanjutnya adalah masuk ketahap proses AHP dan SAW. Pada tahap proses ini lah yang nantinya alternatif dan kriteria akan di sesuaikan dan di cocok kan melaui perhitungan normalisasi pada matriks keputusan (Matriks X) untuk menentukan hasil akhir dari proses perhitungan AHP dan SAW.

5) Yang terakhir adalah tahapan implementasi. Tahapan implementasi ini adalah sebuah tahapan dimana nantinya seluruh hasil dari tahap 1 sampai 4 akan di implementasikan ke dalam sistem yang bertujuan untuk mendapatkan hasil dari sistem pendukung keputusan pemilihan tembakau terbaik.

\section{HASIL DAN PEMBAHASAN}

A. Perancangan Proses Analytical Hierarchi Process (AHP)

Tahapan - tahapan penyelesaian metode Analitical Hierarcy Process (AHP):

a. Menjelaskan Permasalahan yang ada kemudian menentukan solusinya.

Masalah yang terjadi yaitu perusahaan yang masih kesulitan dalam memilih tembakau yang baik sesuai dengan persyaratan kriteria yang telah ditentukan yaitu elastisitas, warna terang, aroma, sortasi, daya bakar (tahan lama) dikarenakan sistem yang belum canggih.

b. Menentukan hierarki berawal dari tujuan utama.

1) Elastisitas lebih Penting dibanding dengan Warna Terang, diberi skala nilai 5

2) Elastisitas Sangat Penting dibanding dengan Aroma, diberi skala nilai 7

3) Elastisitas Nilai Sangat Penting dibanding Sortasi, diberi skala nilai 7

4) Elastisitas Mutlak Lebih Penting dibanding dengan Daya Bakat (Tahan Lam), diberi skala nilai 9

5) Warna Terang Nilai-nilai antara dua nilai pertimbangan yang berdekatan dengan Aroma, diberi skala nilai 2

6) Warna Terang Lebih Penting dibanding dengan Sortasi, diberi skala nilai 5

7) Warna Terang Sangat Penting dibanding Daya Bakar (Tahan Lama) diberi skala nilai 7 
8) Aroma Sedikit Lebih Penting dibanding dengan Sortasi, diberi skala nilai 3

9) Aroma Lebih Penting dibanding dengan Daya Bakar (Tahan Lama), diberi skala nilai 7

10) Sortasi Sedikit Lebih Penting dibanding dengan Daya Bakar (Tahan Lama), diberi skala nilai 3

c. Membuat matriks perbandingan berpasangan antar kriteria setiap Alternatif.

Tabel 8. Matriks Perbandingan Perpasangan setiap Kriteria

\begin{tabular}{|c|c|c|c|c|c|}
\hline $\begin{array}{c}\text { Kriteria: } \\
\text { Kriteria }\end{array}$ & $\mathrm{C} 1$ & $\mathrm{C} 2$ & $\mathrm{C} 3$ & $\mathrm{C} 4$ & $\mathrm{C} 5$ \\
\hline $\mathrm{C} 1$ & 1 & 5 & 7 & 7 & 9 \\
\hline $\mathrm{C} 2$ & 0,2 & 1 & 2 & 5 & 7 \\
\hline $\mathrm{C} 3$ & 0,14 & 0,33 & 1 & 3 & 5 \\
\hline $\mathrm{C} 4$ & 0,14 & 0,2 & 0,33 & 1 & 3 \\
\hline $\mathrm{C} 5$ & 0,11 & 0,14 & 0,2 & 0,33 & 1 \\
\hline Jumlah & 1,59 & 6,67 & 11,53 & 16,33 & 25 \\
\hline
\end{tabular}

d. Menghitung Nilai Eigen Kriteria

Tabel 9. Nilai Eigen

\begin{tabular}{|c|c|c|c|c|c|c|}
\hline CI & C1 & C2 & C3 & C4 & C5 & Priotas \\
\hline C1 & 0.6262 & 0.7307 & 0.6646 & 0.4286 & 0.36 & 0,562 \\
\hline C2 & 0.1252 & 0.1461 & 0.1899 & 0.3061 & 0.28 & 0,209 \\
\hline C3 & 0.0895 & 0.0731 & 0.0949 & 0.1837 & 0.2 & 0,128 \\
\hline C4 & 0.0895 & 0.0292 & 0.0316 & 0.0612 & 0.12 & 0,066 \\
\hline C5 & 0.0696 & 0.0209 & 0.019 & 0.0204 & 0.04 & 0,034 \\
\hline Jlh & 1 & 1 & 1 & 1 & 1 & 1 \\
\hline
\end{tabular}

e. Membuat matriks penjumlah setiap baris ( untuk mencari CI).

Tabel 10. Rasio Konsistensi

\begin{tabular}{|c|c|c|c|c|c|c|}
\hline CI & C1 & C2 & C3 & C4 & C5 & Jlh \\
\hline C1 & 0.6262 & 0.7307 & 0.6646 & 0.4286 & 0.36 & 3,771 \\
\hline C2 & 0.1252 & 0.1461 & 0.1899 & 0.3061 & 0.28 & 1,653 \\
\hline C3 & 0.0895 & 0.0731 & 0.0949 & 0.1837 & 0.2 & 0,897 \\
\hline C4 & 0.0895 & 0.0292 & 0.0316 & 0.0612 & 0.12 & 0,446 \\
\hline C5 & 0.0696 & 0.0209 & 0.019 & 0.0204 & 0.04 & 0,21 \\
\hline
\end{tabular}

Pada langkah perhitungan kali ini peneliti harus memastikan terlebih dahulu tingkat konsisten nya apakah telah terlaksana dengan baik atau tidak. Hal ini bertujuan untuk menghindari sebuah keputusan yang tidak akurat dan memperoleh suatu keputusan yang baik dengan tingkat konsisten yang ada.
Jumlah

$=8,033$

$\mathrm{N}$ (banyaknya kriteria) $=5$

$\lambda$ maks

$=$ Jumlah $/ \mathrm{n}$

$=1,6066$

$=1,12$

$=((\lambda$ maks $-\mathrm{n}) / \mathrm{n})$

$=-0,84835$

$=(\mathrm{CI} / \mathrm{IR})$

$=-0,75745$

Karena, hasil dari perhitungan konsistennya kurang dari nol koma satu $(\mathrm{CR}<0,1)$ maka dapat dikatakan KONSISTEN.

B. Implementasi Proses Metode Simple Additive Weighting (SAW)

Dalam tahap implemntasi, ada beberapa proses diantaranya :

a. Tampilan Sistem Halaman Alternatif

Pada Tampilan Halaman alternatif adalah tahap awal untuk melanjutnya proses selanjutnya.

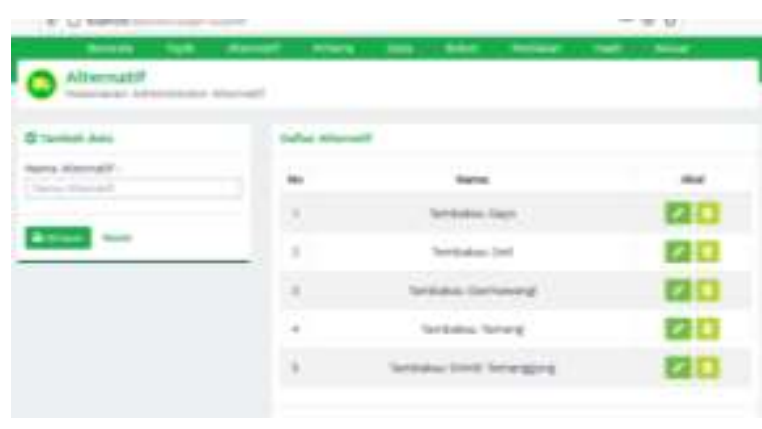

Gambar 3. Tampilan Alternetif

Tampilan alternatif berisikan jenis-jenis tembakau yang di jadikan sampel dalam penelitian ini.

b. Tampilan Halaman Kriteria

Tampilan Halaman Kriteria dapat di lihat pada gambar di bawah ini :

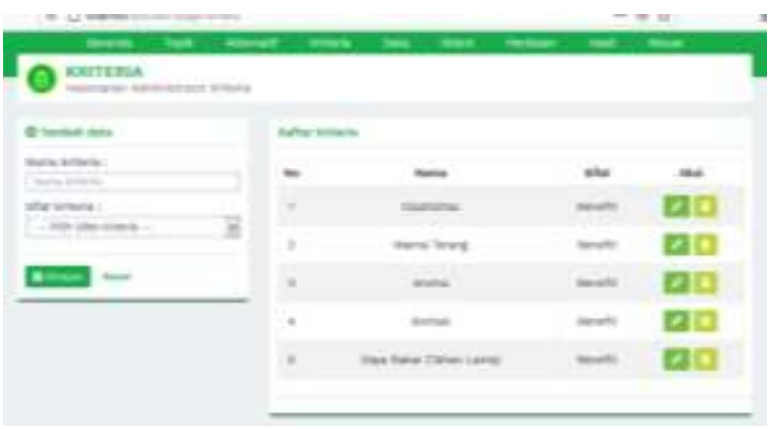

Gambar 4. Tampilan Kriteria

Pada tampilan kriteria berisi kan kriteria-kriteria yang menjadi pilihan dalam penelitian ini sesuai dengan persyaratan perusahaan nya. 
c. Tampilan Normalisasi Matriks Keputusan

Tampilan Hasil Perangkingan dapat di lihat seperti gambar dibawah ini :

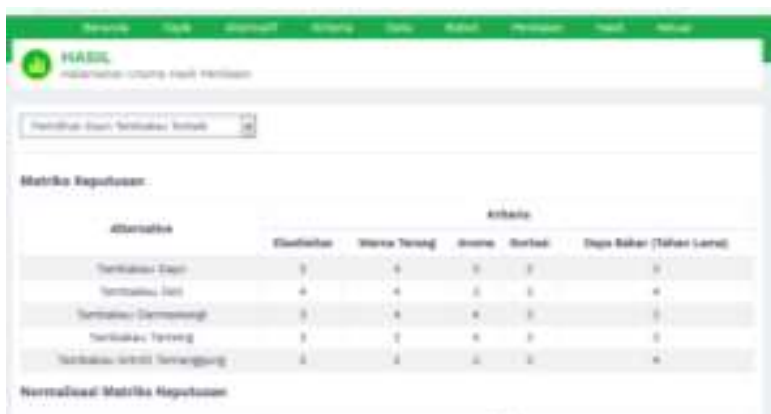

Gambar 5. Tampilan Normalisasi Matriks Keputusan

Pada halaman matris keputusan semua data yang ada di halaman ini adalah hasil perhitungan dari datadata yang telah diproleh.

d. Tampilan Halaman Perangkingan

Halaman Perangkingan disajikan pada gambar dibawah ini :

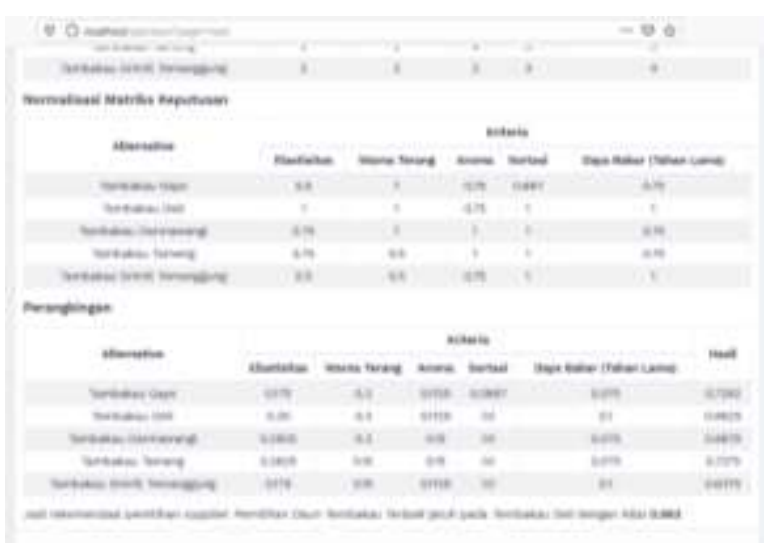

Gambar 6. Tampilan Perangkingan

Dari hasil perangkingan seperti gambar di atas (Gambar 4) dapat di simpulkan bahwa pemilihan daun tembakau terbaik jatuh pada Temabaku Deli dengan angka 0,963 .

\section{KESIMPULAN}

Dari hasil penelitian di atas dapat di simpulkan bahwa, Tembakau Deli menepati kedudukan Tembakau Terbaik. Maka dari hasil penyataan di atas adalah, pemilihan termbakau terbaik di berikan kepada Tembakau Deli.

\section{DAFTAR PUSTAKA}

[1] J. Iriani et al., "Implementation of Promethee Method in Decision Support System for," vol. 5, no. 2, pp. 172-184, 2017.

[2] Y. H. Siregar, M. D. Irawan, and A. H. A. Chaniago, "Penerapan Metode Analytical Hierarchy Process (AHP) dalam Perekrutan Petugas Keamanan," J. Inform. Univ. Pamulang, vol. 5, no. 3, p. 371, Sep. 2020, doi: 10.32493/informatika.v5i3.6550.

[3] A. Widarma, Y. Handika Siregar, M. D. Irawan, and S. Fadhillah, "Sistem Pendukung Keputusan Menentukan Tempat KKN (Kuliah Kerja Nyata) Menggunakan Metode Logika Fuzzy," CESS (Journal of Computer Engineering, System and Science). 2020. doi: 10.24114/cess.v5i2.19665.

[4] M. D. Sinaga, B. S. Riza, J. Iriani, I. Lazuly, Daifiria, and E. H. Victor, "A Forward Chaining Trace Analysis in Diagnosing Tamarillo Disease," 2018 6th Int. Conf. Cyber IT Serv. Manag. CITSM 2018, no. Citsm, pp. 14, 2019, doi: 10.1109/CITSM.2018.8674292.

[5] R. Prasetiyo, S. Sumiati, and I. Iriani, "Pemilihan Supplier Tembakau Sebagai Bahan Baku Rokok Menggunakan Metode Analytic Network Process (Anp) Di Pabrik Rokok Alaina," Tekmapro J. Ind. Eng. Manag., vol. 13, no. 1, pp. 41-54, 2019, doi: 10.33005/tekmapro.v13i1.60. 